\title{
Local Wisdom-Based Women's Empowerment: Study of Rattan Weaving Craftsmen in the Betang Asi Credit Union Cooperative Business Group in Pulang Pisau Regency, Central Kalimantan Province
}

\author{
Rita Sarlawa ${ }^{1}$, Saputra Adiwijaya ${ }^{2}$ \\ ${ }^{1}$ Lecturer of Management Department, Faculty of Economics and Business, University of Palangka Raya, \\ Indonesia \\ ${ }^{2}$ Lecturer of Sociology Department, Faculty of Social and Political Sciences, University of Palangka Raya, \\ Indonesia \\ s_adiwijaya@gmail.com
}

\begin{abstract}
The independence of society is inseparable from the emergence of the independence of individuals who are in it, including women. Women who are members of the Betang Asi Credit Union Cooperative business unit in Pulang Pisau Regency, Central Kalimantan Province with their efforts to wick rattan provide a new meaning in empowering women based on local wisdom of Dayak tribe, with a focus on business based on the potential of rattan plants that grow in nature. This research uses a descriptive qualitative method with a case study approach. The results of this study provide a review of the need for women to join business institutions such as cooperatives or other institutions in marketing their products, so that the weaknesses of the findings in this study can be eliminated and the role of women in the village towards economic independence can run well without having to forget the local wisdom as a person born from Dayak tribe.
\end{abstract}

Keywords: Women's empowerment; Dayak tribe; rattan weaving; CU Betang Asi

\section{Introduction}

The current development paradigm has provided opportunities for the community to actively participate in developing all kinds of creativity in order to create sustainable independence, independence that can provide a solution in solving the problem of poverty.

Poverty is not only interpreted as a limitation in meeting the needs of life, but has many reviews, by Tjokrowinoto in Sulistiyani (2017) states that poverty is not only about welfare issues; but poverty concerns vulnerability, powerless, closed access to various job opportunities, spends most of its income for consumption needs, high dependency rates, low access to markets, and poverty is reflected in a culture of poverty inherited from one generation to next generation.

One that can be a reference in understanding multidimensional poverty is poverty in women, especially in rural areas. Social construction that is still happening is the marginalization of women which then makes the capacity of poverty for women a heavier burden than men. The vague impact that can be seen from this situation gives an indication that poverty that occurs if based on gender actually makes the sharpness of gender inequality.

By Indraswari (2012) mentions from the quantitative side based on data from the United Nations reporting that of 1.3 billion world population included in the category of absolute poverty, $70 \%$ are women. Similarly, in terms of qualitative gender inequality results among the poor, women are the poorest (women are the poorest of the poor).

From this situation for Pulang Pisau Regency which is part of Central Kalimantan Province, women's empowerment can be a reference to provide solutions to the poverty situation that occurs. Women in the region have businesses that are very closely related to local wisdom. During this time, women in Pulang Pisau Regency worked to wick rattan to produce products such as mats, bags and 
hats. The work carried out is work done for generations, but there is a constraint that is classic when these women experience limited capital and constraints when marketing products.

Credit Union Betang Asi Cooperative through its branches in Pulang Pisau Regency synergizes in efforts to empower women by carrying out various activities to provide knowledge and insight as well as capital assistance in developing the business undertaken.

\section{Research Methods}

This research uses qualitative research methods with a case study approach to empowering women based on local wisdom. The data collected is based on interviews with 5 (five) women who worked as rattan woven craftsmen under the guidance of Credit Union Betang Asi Cooperative, Pulang Pisau Regency. The case study approach according to Ary in Idrus (2009) as an intensive investigation of an individual, but case studies can also be used to investigate small social units such as families, schools, or groups.

Then to test the validity of the data obtained so that it is truly in accordance with the aims and objectives of the study, the researchers used triangulation techniques. According to Moleong (2007), data triangulation is a data checking technique that utilizes something other than the data for checking or comparison purposes.

Whereas for data analysis researchers are guided by the interactive technique of Miles and Huberman in Sugiyono (2008) that the activities in qualitative data analysis are carried out interactively and continuously until completion, so that the data is already saturated. Activities in data analysis are data reduction, data display, and conclusion drawing / verification.

\section{Discussion}

\subsection{Village Women and Poverty Vulnerability}

Poverty as described previously is very multidimensional so that when it is later revealed in a rural area analysis and is specific to one gender (women), it is expected to be a solution in efforts to alleviate the problem of poverty itself.

Poverty in rural Indonesia is more evident than in urban areas. If the city seems to be shrouded by a variety of active economic activities, it is precisely in villages where poverty is suffered by its citizens very clearly, especially if the main indicator is the ability to meet standard needs. If there is famine, people in the village look more miserable and really have nothing.

According to Suharto (2014) poverty is a social problem that is always present in the midst of society, poverty is a concept and phenomenon that faces a face, multidimensional dimension. SMERU, for example, shows that poverty has several characteristics which are as follows:

A. Inability to meet basic consumption needs (boards, clothing, food).

B. Lack of access to other basic necessities of life such as

1) Health

2) Education

3) Sanitation

4) Clean water

5) Transportation

C. Lack of future guarantees (due to lack of investment in education and family).

D. Vulnerability to individual or mass shocks.

E. Low quality of human resources and limited natural resources. 
F. Not involved in social activities.

G. Lack of access to employment and sustainable livelihoods.

$\mathrm{H}$. Inability to try because of physical and mental disabilities.

I. Such social incapacity and disadvantage

1) Homeless child

2) Women victims of domestic violence (domestic violence)

3) Poor widow

4) Marginal and isolated groups

The poverty suffered by rural women in Indonesia cannot be likened to the case. This situation actually makes the policy or program made by the government also diverse. On the other hand, when the policy or program is implemented it is not entirely successful but instead it creates new problems at the level of implementation.

Therefore, Whitehead (2003) in Indraswari (2012) illustrates that poverty is more complexly gendered, as men and women are often poor for different reasons, experience poverty differently, and have differing capacities to withstand or escape poverty. Vulnerability experienced women in facing poverty are different from those experienced by men, this situation can then become more severe when poverty has a chain effect, for example health is increasingly declining, education is low, to lead to other social problems such as high crime rates.

Furthermore Indraswari (2012), quoting from the World Bank (2003), identifies poverty related to women into four dimensions, namely:

A. Women's lack of empowerment

In this section it is said that there are weaknesses in terms of women's empowerment which includes: (1) Empowerment in the economic sector is related to the lack of / weak access of women to formal financial institutions. (2) Empowering women who also experience weaknesses in decision making at national and regional levels. Both of these can be illustrated that assets that can be guaranteed are usually in the name of men, so that access in the formal financial side is hampered. Then on the other hand there is still not a low number of women working in the formal sector to become civil servants, officials, or leaders. But over time this condition has undergone many changes, it's just that if in a rural context, women are still not fully empowered.

B. Women's lack of opportunity

In this section discrimination against lower salary systems is a reference, that women who work as laborers experience more workloads but receive the same wages as men, or in certain occupations there is even no insurance coverage from the place of work.

C. Women's lack of capacity

The still low level of education and health status for women is the focus of women's subsequent vulnerability. In rural areas, in general women are still few who are able to complete education above high school, in fact it can be said that the average education of women in the village is junior high school. If related to the context of women's health, they have not yet fully gained access to health, in the current context in Indonesia the high level of stunting is one example which is then closely related to the high age of child marriage, especially at the rural level.

D. Women's lack of security

The poverty factor also affected the high level of violence against women, according to Komnas Perempuan's annual records (2019), there are 406,178 cases of violence against women reported and deal with during 2018 (up from 348,466 in the previous year). Cases of violence against women consisted of 13,568 cases handled by 209 service provider partner institutions spread across 34 Provinces, and 392,610 cases are sourced from case data handled by the Religious Courts. 
Noting the four things above can be a frame of analysis of the vulnerability of women in rural areas that there is a veil of what is actually happening, because actually women in conditions that are vulnerable to poverty can become more empowered by still making the culture in the village as a "weapon" in improve the lives of the villagers in general.

\subsection{Business Sector Credit Union Betang Asi Cooperative}

For Pulang Pisau Regency, there are a number of business units that are guided by Credit Union Betang Asi Cooperative, as shown in the table below:

Table 1. Types of CU Betang Asi Guided Enterprises in Pulang Pisau Regency in 2019

\begin{tabular}{|l|l|c|l|}
\hline No. & \multicolumn{1}{|c|}{ Type of Business } & $\begin{array}{c}\text { Number of Actors / } \\
\text { Groups Usaha }\end{array}$ & Information \\
\hline 1. & Fish Cultivation & 1 & \\
\hline 2. & Farming Pigs & 9 & \\
\hline 3. & Farming Goat & 2 & \\
\hline 4. & Farming Cow & 1 & \\
\hline 5. & Farming Chicken & 1 & \\
\hline 6. & Rattan Crafts & 1 & Organic Rice \\
\hline 7. & Agriculture & 1 & Selling groceries \\
\hline 8. & Trading & 17 & \\
\hline 9. & Total & & \\
\hline
\end{tabular}

Source: Research Results Processed, 2019.

From the table above, there are nine business fields that are operating in 2019 and are active, based on data obtained also specifically for Pulang District funds rolled out by Betang Asi CU Cooperative in the amount of Rp. 612,000,000 from a total of Rp. 9,160,447,300 for all branches of Betang Asi Cooperative in Central Kalimantan.

The focus of research in this study is in the field of rattan handicraft business, in this business sector there are 5 craftsmen all of whom are women. In the context of natural conditions that are rich in rattan in Pulang Pisau, many other rattan craftsmen, especially women, only joined the Betang Asi Cooperative as a group.

Joining these women in addition to guarantees in the form of land ownership documents (SHM), also get other facilities such as low installments, and get fostered which is constantly monitored regularly so that in developing their business can be as expected. During this time if through a bank, it is almost said there is no intensive coaching after the disbursement of funds is considered complete. This is what distinguishes the mechanism in the bank.

\subsection{Potential Rattan and Women's Business Based on Local Wisdom}

Realizing that rattan has become a potential that can develop, Government of Central Kalimantan Province has made improvements to the potential of this natural resource through community empowerment programs related to the development of the rattan industry, in the form of furniture processing training. According to Budiono (2017), quoting from Metro7 media in Adiwijaya (2018), it was stated that in 2013 the regencies namely South Barito, North Barito and East Barito had signed a memorandum of understanding (MoU) or 
memorandum of understanding on the development of the rattan industry with private companies, then in 2015 the government inaugurated the first rattan Warehouse Receipt System (SRG) in Indonesia, located in the Hampangen Rattan Industrial Zone, Katingan Regency. This situation then by the Ministry of Trade in daily of Republika online media on Thursday, December 24, 2015 added that the development of the Warehouse Receipt System (SRG) commodity, especially rattan has the aim that the production of rattan produced in the production center area can be absorbed easily and guaranteed quality by the industry. The availability of rattan stock that meets the needs of the rattan industry can be a major capital for the growth of a competitive domestic rattan industry, able to optimize upstream and downstream integration, between the needs of farmers and industry. It gives a very strategic picture of the potential of rattan plants for Central Kalimantan as a commodity that is expected to provide a number of benefits for the government and its people.

Furthermore, in addition to the four regencies, Kapuas Regency also continues to develop rattan handicraft industrial centers which are the mainstay products. At least, the area has two centers for the development of the rattan handicraft industry. The local government of Kapuas Regency has built an industrial center in West Kapuas District, Mandomai Village and in 2017 will be built in Selat District, precisely in Pulau Telo. Village. Likewise for Pulang Pisau Regency which develops Rattan Industrial Centers in Gohong Village. In these two districts, indeed the distance is close together and so far access to the Province of South Kalimantan has made craftsmen in these two districts market products such as rattan mats.

On the other hand, if viewed further, there is a gap when nature in the province of Central Kalimantan, especially in Pulang Pisau Regency, which is rich in forest products, but many of its inhabitants still experience vulnerability in poverty, especially for women. When this condition was later understood to change the work that women had done for generations as Dayaks, it actually turned out to be wrong, because Dayak women who had the skill of waving cane were not ordinary women. But independent women who are seen in terms of their ability to maintain a local wisdom that will intersect with their role in protecting nature.

Rattan as a typical plant for Dayaks in Central Kalimantan has given its own meaning when rattan has become a product so there is a review of the discussion in this analysis that women's empowerment is created because of the opportunity for entrepreneurship that is one of the pillars of society, especially the Dayak community. On the other hand, when the commodity of rattan has provided opportunities for increased income of Dayak women there is created an awareness to care more about protecting nature, this is also sustained to maintain identity as Dayaks who are also more concerned with the craft of local products. This is marked by the familiarity of rattan products that are easily found and used.

Rattan weaving women who are members of the Betang Asi Credit Union Cooperative group in Pulang Pisau Regency - Central Kalimantan Province have obstacles which in this case can be said to be an obstacle to their independence. The constraints that can be inventoryed from this study include the following:

A. Availability of Rattan Raw Materials

Rattan raw materials that exist in nature cannot always be available, this is due to the increase in forest fires where rattan grows. So far, the rattan used as raw material is the result of rattan seekers and collectors, because the rattan that grows is not from cultivation but grows wild in the forest. According to hot spot data per January-14 September 2019 in Pulang Pisau Regency, 4,263 got spots were recorded, with 163 incidents of forest and land 
fires, and $985 \mathrm{Ha}$ of burned land. (https://www.mongabay.co.id/2019/09/16/asap-pekatberbahaya-terus-selimuti-palangkaraya/).

One of the most common causes of these fires is the conversion of land so that burning land is an effective way of clearing land, this is based on research from the CSF (Conservation Strategy Fund) in collaboration with the Pulang Pisau Regency Government in 2018 which states that based on analysis and identify the relationship between land use change with forest fires and land in Pulang Pisau Regency utilizing hotspot data in 2014 and 2015, 2016 land cover, results of identification of community oil palm plantations, area of forest and land fires in 2015 and field observations. This is also based on the previous condition that the initial condition of land cover in 2014 in Gandang Barat Village (as a research locus) is paddy fields. While the existing conditions are dominated by abandoned land, consisting of shrubs and galam plants based on the results of interviews with the Village Head with a number of 2014 hotspots as much as one point. Then in 2015 many West Gandang villagers cleared land to prepare for planting oil palm based on interviews with the Head Village. Furthermore, in the same year, there were 48 hotspots. This means that there is an increase in the number of hotspots at the same time as land clearing for oil palm cultivation.

This is enough to illustrate that land use change has a role in the rise of forest and land fires, and this has an impact on the availability of rattan raw material.

B. Marketing

The marketing of products for women woven rattan craftsmen who are members of the Credit Union Betang Asi Cooperative Business Group in Pulang Pisau Regency, Central Kalimantan Province, is still a significant obstacle. If it is further examined marketing has only relied on events held by the government. the area is good in the scale of the district government Pulang Pisau, Central Kalimantan Province, and occasionally attend a national event. While the event conducted by Credit Union Cooperative is also not routine because it only relies on the Annual Member Meeting once a year.

Making the field of marketing as an urgent matter, can be seen in terms of the combined marketing (marketing mix) according to Kotler and Armstrong (2012: 75), "Marketing mix is the set of tactical marketing tools that the firm blends to produce the response it wants in the target market", meaning that the combined marketing is a set of tactical marketing tools that integrate the company to produce the desired response in the target market. The marketing mix consists of 4 (four) components in a marketing strategy called 4P, namely:

1) Product is a product, service or idea that is designed and offered by a company for the needs of consumers.

2) Price is the amount of money a customer must pay to get a product.

3) Place (place, including distribution) is the placement of a product to be available to target consumers, a type of activity related to how to deliver products from producers to consumers.

4) Promotion is the activity of communicating and delivering information about products to consumers, and persuading target consumers to buy products.

\section{Quasi-competition among Rattan Weaving Women's Groups}

In this research, it is found that there is an unhealthy competition among women, in a pseudo sense. This is marked by a reluctance to share when a group got product orders or 
information related matters when there was an exhibition event. also exacerbated by the inability to provide stock when there are many orders, even if a product such as a bag can be delegated to other craftsmen groups, orders that have been received can be completed in a timely manner, this constraint also affects the product yields because pursuing the number of orders actually neglects the quality then the finished product seems as it is. There is a mismanagement related to the product being ordered, then ignores the quality of the product excellence, so that competitiveness also decreases.

\section{Conclusion}

The empowered women are independent women. Women who are able to develop the potential they have so that many provide benefits to the surrounding environment. The group of women who are members of Credit Union Betang Asi Cooperative Business Group in Pulang Pisau Regency, Central Kalimantan Province have done so by making woven from raw rattan. Despite the shortcomings, this group has a mission as a savior of the local value of the products produced. There is a belief that this group can develop as a prototype in the focus of empowering women based on local wisdom as its philosophical values.

\section{References}

Adiwijaya, Saputra and Pipit Ningrum. (2018). Pemberdayaan Masyarakat Melalui Kewirausahaan Pada Industri Kecil Menengah (IKM) Di Kalimantan Tengah Sebagai Salah Satu Unsur Dalam Perubahan Sosial (ISSN 2239 -2274). Jurnal Sosiologi Volume VI No. 1 January-June 2018.

Edi, Suharto. (2014). Membangun Masyarakat Memberdayakan Rakyat (Kajian Strategis Pembangunan Kesejahteraan Sosial \& Pekerjaan Sosial). PT. Refika Aditama. Bandung.

Idrus, Muhammad. (2009). Metode Penelitian Ilmu Sosial-Pendekatan Kualitatif dan Kuantitatif (Edisi Kedua). Erlangga. Jakarta.

Indraswari. (2012). Pembangunan dan Kemiskinan Perempuan. Jurnal Analisis Sosial. Vol.17. No. 2, Desember 2012 (ISSN 1411 - 0024). Yayasan Akatiga. Bandung.

Kotler, Philip and Gary Armstrong. 2012. Prinsip-prinsip Pemasaran. Edition. 13. Volume 1. Jakarta: Erlangga.

Moleong, Lexy J. (2007). Metodologi Penelitian Kualitatif, Penerbit PT Remaja Rosdakarya. Offset. Bandung

Sugiyono. (2008). Metode Penelitian Kunatitatif Kualitatif dan R\&D. Alfabeta. Bandung.

Sulistiyani, Ambar Teguh. (2017). Kemitraan dan Model-Model Pemberdayaan. Gava Media. Whitehead, Ann. (2003). Failing Women, Sustaining Poverty : Gender in Poverty Reduction Strategy Papers, Reports for the UK Gender and Development Network.

World Bank. (2003). Gender Equality and the Milenium Development Goals.World Bank.

\section{Internet Source :}

https://www.komnasperempuan.go.id/read-news-lembar-fakta-dan-poin-kunci-catatantahunan-komnas-perempuan-tahun-2019, diakses 29 September 2019. Pukul 22.32 WIB 
https://nasional.republika.co.id/berita/nzv321359/sistem-resi-gudang-rotan-dapat-tingkatkandaya-saing, accessed 29 September 2019. At 22.56 WIB.

https://www.mongabay.co.id/2019/09/16/asap-pekat-berbahaya-terus-selimuti-palangkaraya/, accessed September 30, 2019. At 23.19 WIB.

\section{Research Source :}

Analisis Kebakaran Hutan Dan Lahan Akibat Alih Fungsi Lahan Di Kabupaten Pulang Pisau. (2018). Pemerintah Kabupaten Pulang Pisau bekerjasama dengan Conservation Strategy Fund (CSF) 